\title{
АНТИГЕННЫЕ ВЗАИМОСВЯЗИ И БИОЛОГИЧЕСКИЕ СВОЙСТВА ШТАММОВ ВИРУСА СВИНОГО ГРИППА А/Н1N1, ВЫДЕЛЕННЫХ В СЕВЕРНОМ КАЗАХСТАНЕ В 2018 ГОДУ
}

\author{
Н.Т. САКТАГАНОВ, Н.Г. КЛИВЛЕЕВА, Н.С. ОНГАРБАЕВА, Т.И. ГЛЕБОВА, \\ Г.В. ЛУКМАНОВА, А.М. БАЙМУХАМЕТОВА
}

\begin{abstract}
Грипп свиней - высококонтагиозная, остро протекающая болезнь, характеризующаяся резко выраженной лихорадкой, общей слабостью и поражением органов дыхания. Вирус гриппа свиней способен вызывать заболевание у людей, также установлена возможность заражения свиней вирусом гриппа человека. В организме свиньи при одновременном заражении вирусами разного происхождения происходит генетическая реассортация с риском появления новых опасных высокопатогенных штаммов. Изучение вирусов гриппа, циркулирующих в популяции свиней, играет важную роль для предотвращения развития опасных вспышек заболевания и планирования профилактических мероприятий. В нашей работе при изучении биологических свойств штаммов вируса гриппа A/H1N1 в популяции свиней в Северном Казахстане мы впервые установили более высокую степень сходства изолятов с классическими вариантами вируса гриппа свиней A/H1N1 (A/Swine/USA/1976/31 и A/swine/Iowa/15/30), чем с циркулирующими в настоящее время в человеческой популяции штаммами, родственными А/California/04/09 pdm. Кроме того, выявлена чувствительность изолированных штаммов к противогриппозным препаратам адамантанового ряда (ремантадин) и ингибиторам нейраминидазы (тамифлю), а также резистентность к арбидолу и ингавирину. Нашей целью было выявление биологических и антигенных особенностей штаммов вируса гриппа свиней $\mathrm{A} / \mathrm{H} 1 \mathrm{N1}$, циркулировавших в Северо-Казахстанской области Республики Казахстан. Исследовали штаммы вируса гриппа А/H1N1 - А/свинья/Петропавловск/01/18, А/свинья/Петропавловск/02/18 и А/свинья/Петропавловск/03/18, выделенные в 2018 году из проб в свиноводческих хозяйствах Северо-Казахстанской области, и референсные варианты A/swine/Iowa/15/30, A/swine/USA/1976/31 и A/California/04/09 pdm. Штаммы размножили в 10-суточных развивающихся куриных эмбрионах (КЭ). Антигенные свойства поверхностных гликопротеидов исследовали в перекрестной реакции торможения гемагглютинации с кроличьими иммунными сыворотками. Инфекционность определяли на куриных эмбрионах и в культуре клеток MDCK. Адсорбционные свойства изучали в течение 18 ч на формалинизированных куриных эритроцитах при постоянном помешивании при $4{ }^{\circ} \mathrm{C}$. Элюцию с эритроцитов определяли через $30,60,120,180$ и 240 мин в забуферном физиологическом растворе при $37{ }^{\circ} \mathrm{C}$. Термочувствительность гемагглютинина оценивали по способности агглютинировать эритроциты после прогревания при $56{ }^{\circ} \mathrm{C}$ в течение $5,10,15,30$ и 60 мин. Гемагтлютинирующую активность штаммов устанавливали с $0,75 \%$ суспензиями эритроцитов курицы, морской свинки, барана, лошади и человека с группой крови I(0) в реакции гемагглютинации. Чувствительность изолятов к неспецифическим ингибиторам определяли в реакции торможения гемагглютинации с нативными и прогретыми (30 мин при $62^{\circ} \mathrm{C}$ и 10 мин при $\left.100{ }^{\circ} \mathrm{C}\right)$ сыворотками крови морской свинки, курицы и кролика. Чувствительность штаммов вируса к различным концентрациям противовирусных препаратов оценивали по степени подавления репродукции $100 \mathrm{lg}$ ЭИД Было выявлено антигенное родство изучаемых вариантов вируса гриппа A/H1N1 между собой и с эталонами A/swine/USA/1976/31 и A/Swine/Iowa/15/30 и их отличие от A/California/04/09 pdm. Исследованные штаммы в высоких титрах агглютинировали все виды эритроцитов в эксперименте. Инфекционная активность штаммов вируса гриппа свиней на куриных эмбрионах варьировала в пределах 6,5-7,9 lg ЭИД $50 / 0,2$ мл, в культуре клеток МDCK - 3,5-4,3 lg ТЩД сле прогревания при $56{ }^{\circ} \mathrm{C}$ все штаммы агглютинировали эритроциты курицы в высоких титрах $\left(\log _{2}=6,3 \pm 0,6-9,6 \pm 0,8\right)$ и были охарактеризованы как термостабильные. Выделенные штаммы обладали хорошей адсорбирующей способностью по отношению к эритроцитам кур (90-100\%) и элюировались с них через 30-60 мин инкубации при $37^{\circ} \mathrm{C}$. Штаммы проявляли резистентность к ингибиторам нативных неспецифических сывороток и подавлялись ингибиторами только прогретых сывороток. Исследуемые штаммы оказались чувствительными к тамифлю и ремантадину (ингибирующая концентрация соответственно 5,6-6,6 и 3,7-12,7 мкг/мл). По отношению к препаратам арбидол и ингавирин проявляли резистентность. Таким образом, выявлено сходство выделенных и референсных штаммов A/H1N1 по термостабильности гемагглютинина, скорости адсорбции и чувствительности к противовирусным препаратам, различия по инфекционной активности и скорости элюции с куриных эритроцитов.
\end{abstract}

Ключевые слова: вирус свиного гриппа, A/H1N1, штамм, изолят, антиген, гемагглютинин, инфекционность, термостабильность, резистентность, чувствительность к препаратам. 
Вирусы гриппа рода А - уникальные инфекционные агенты человека, а также ряда млекопитающих и птиц $(1,2)$. Вопрос межвидовой трансмиссии вирусов гриппа $\mathrm{A}(\mathrm{H} 1 \mathrm{~N} 1)$ человека и животных важен для изучения эволюции, экологии и эпидемиологии возбудителя. Существуют теоретические обоснования возможности передачи вируса гриппа А между птицами околоводного комплекса и другими морскими обитателями, птицами и свиньями, тюленями и людьми, свиньями и людьми $(3,4)$.

Часто у свиней, зараженных вирусом гриппа, клинические признаки заболевания не проявляются, а смертность не превышает 1-4 \%. В условиях умеренного климата животные могут быть инфицированы вирусом гриппа круглый год, но в холодное время вероятность заражения повышается (5).

Вирус гриппа свиней обнаружен во многих странах с развитым животноводством, в том числе в Казахстане (6-9). В настоящее время в популяциях свиней выявлены три подтипа вируса гриппа А: H1N1, H3N2, $\mathrm{H} 1 \mathrm{~N} 2$. Антигенно отличающийся вариант H1N1 птичьего происхождения у свиней выделяют с 1979 года. Наиболее распространен A/H1N1, антитела к которому выявлены у свиней во всех странах мира (10). Штаммы вируса гриппа с антигенной формулой A/H3N2, ставшие результатом межвидовой трансмиссии вируса от человека к свиньям, впервые обнаружены в 1970 году. Штаммы А/H1N2, выделенные от свиней в 1994 году как результат реассортации вирусов гриппа свиней, человека и птиц, продолжают циркулировать и по настоящее время (11).

Свиньи заражаются вирусами гриппа человека и птиц. При одновременном заражении этими двумя вирусами происходит обмен наследственным материалом между штаммами различного происхождения, в результате вновь появившиеся вирионы приобретают способность передаваться от человека к человеку с вероятностью развития пандемии (12).

Постоянный мониторинг распространения возбудителя инфекции, расшифровка этиологии заболевания, всесторонняя характеристика инфекционного агента играют важную роль в разработке и планировании мероприятий по предотвращению возможной эпизоотии. Определение биологических и антигенных особенностей циркулирующих вирусов позволяет выявить главные направления изменчивости, филогенетические взаимосвязи штаммов, обнаруженных ранее и постоянно появляющихся в различных странах и регионах. Сведения об эпидемически актуальных штаммах дают возможность понять истоки текущих и будущих эпидемий и наиболее точно подобрать средства и способы профилактики гриппа, а также стратегию лечения.

В представляемой работе при изучении биологических свойств штаммов вируса гриппа A/H1N1, выделенных в популяции свиней в Северном Казахстане, мы впервые установили более высокую степень сходства этих штаммов с классическими вариантами вируса гриппа свиней A/H1N1 (A/Swine/USA/1976/31 и A/swine/Iowa/15/30), чем с циркулирующими в настоящее время в человеческой популяции штаммами, родственными штамму A/California/04/09 pdm. Кроме того, обнаружена чувствительность изолированных штаммов к противогриппозным препаратам адамантанового ряда (ремантадин) и ингибиторам нейраминидазы (тамифлю), а также резистентность к арбидолу и ингавирину.

Нашей целью было выявление биологических и антигенных особенностей штаммов вируса гриппа свиней А/H1N1, циркулировавших в Северо-Казахстанской области Республики Казахстан в 2018 году.

Методика. В исследованиях использовали штаммы вируса гриппа 
A/H1N1, выделенные из проб, собранных в 2018 году в свиноводческих хозяйствах Северо-Казахстанской области (А/свинья/Петропавловск/01/18, А/свинья/Петропавловск/02/18 и А/свинья/Петропавловск/03/18), а также референсные штаммы - A/Swine/Iowa/15/30, A/swine/USA/1976/31 и A/California/04/09 pdm (коллекция лаборатории биохимии вирусов, ТОО Научно-производственный центр «Микробиологии и вирусологии»). Клонирование вирусов осуществляли в системе 10-суточных развивающихся куриных эмбрионов (КЭ) с инокуляцией вирусного материала в хорионаллантоисную полость. Собранную аллантоисную жидкость центрифугировали при 24000 об/мин в течение 180 мин при $+4{ }^{\circ} \mathrm{C}$. Дальнейшую очистку и концентрирование вирусного материала проводили в градиенте плотности сахарозы на центрифуге Beckman («Beckman Coulter», США; ротор Ті 45, 37000 об/мин, 90 мин, $\left.+4{ }^{\circ} \mathrm{C}\right)(13)$.

Антигенные свойства поверхностных гликопротеидов штаммов исследовали в перекрестной реакции торможения гемагглютинации (РТГА) в соответствии с рекомендациями Всемирной организации зравоохранения (14) с использованием кроличьих иммунных сывороток (15). Специфические гипериммунные кроличьи сыворотки получали 3-кратной иммунизацией кроликов породы шиншилла массой 2,5-3 кг. Концентрированный вирус вводили подкожно в дозе 150 мкг/животное с интервалом 21 сут. Специфическую активность полученных гипериммунных кроличьих сывороток определяли в РТГА с набором антигенов для диагностики вирусов гриппа (ООО «ППДП», г. Санкт-Петербург, Россия) с антигенными формулами A/H1N1, A/H3N2 и типа В.

Инфекционность выделенных штаммов определяли на 10-суточных КЭ и в культуре клеток MDCK (Madin-Darby canine kidney, перевиваемая культура клеток эпителия почки собаки, АТCC Catalogue of cell lines \& hybridomas, $7^{\text {th }}$ edn. Rockville, MD, 1992) по методу L. Reed и H. Muench (16) на основании оценки эмбриональной инфекционной дозы и тканевой цитопатогенной дозы и выражали соответственно в $\lg$ ЭИД и $\lg$ ТЦД $50 / 0,2$ мл.

Адсорбционные свойства штаммов изучали при $4{ }^{\circ} \mathrm{C}$ в течение 18 ч на $50 \%$ формалинизированных куриных эритроцитах при постоянном помешивании. Формалинизированные эритроциты кур получали обработкой предварительно отмытых эритроцитов кур 40 \% раствором формальдегида в пропорции 1:1. После контакта эритроцитов с формалином в течение 6 сут при периодическом ресуспендировании формалин удаляли многократным отмыванием стерильным физиологическим раствором с последующим центрифугированием при 3000 об/мин (Rotanta 460, «Hettich», Германия). Элюцию с эритроцитов учитывали при $37{ }^{\circ} \mathrm{C}$ в забуферном физиологическом растворе через 30, 60, 120, 180 и 240 мин. Термочувствительность гемагглютинина (ГА) оценивали по способности вирусов агглютинировать эритроциты после прогревания при $56{ }^{\circ} \mathrm{C}$ в течение $5,10,15$, 30 и 60 мин (17). Гемагглютинирующую активность штаммов устанавливали с $0,75 \%$ суспензиями эритроцитов курицы, морской свинки, барана, лошади и человека с I(0) группой крови в реакции гемагглютинации (РГА) (18). Эритроциты трижды отмывали в стерильном забуференном физиологическом растворе осаждением в течение 10 мин при 1500 об/мин (СМ6M, «Elmi», Латвия). Из осадка отмытых эритроцитов готовили $0,75 \%$ суспензию.

Чувствительность изолятов к неспецифическим ингибиторам определяли в РТГА с полученными нативными и прогретыми (30 мин при $62{ }^{\circ} \mathrm{C}$ и 10 мин при $100{ }^{\circ} \mathrm{C}$ ) сыворотками крови морской свинки, курицы и 
Чувствительность выделенных штаммов к различным концентрациям противовирусных препаратов оценивали по степени подавления репродукции 100 ЭИД $50 / 0,2$ мл вируса на КЭ. Для изучения чувствительности использовали лекарственные средства ремантадин (100 мг/капсула, АО «Olainfarm», Латвия), тамифлю (75 мг/капсула, «Cenexi SAS», Франция, упаковано «F. Hoffmann-La Roche AG», Швейцария), арбидол (100 мг/капсула умифеновира гидрохлорида моногидрата в пересчете на умифеновира гидрохлорид, ОАО «Фармстандарт-Лексредства», Россия); ингавирин (90 мг/капсула имидазолилэтанамида пентандиовой кислоты - витаглутама, ОАО «Валента Фармацевтика», Россия). Препараты растворяли в фосфатно-буферном растворе в концентрации 50 мг/мл, полученные растворы использовали в качестве исходных. Дозу препарата, подавляющую титр вируса в РГА в 2 раза по сравнению с контролем, считали ингибирующей концентрацией $\left(\right.$ ИК $\left._{50}\right)(19)$.

Статистическую обработку результатов проводили с помощью программного обеспечения Microsoft Office Excel 2010. Для всех серий результатов находили средние геометрические обратных логарифмов титров гемагглютинации по основанию 2 (geometric mean titer, GMT) и определяли их стандартные отклонения $( \pm \mathrm{SD})$.

Результаты. Для изучения антигенных взаимосвязей выделенных штаммов вирусный материал, накопленный в КЭ, после очистки концентрировали в фосфатно-буферном растворе в объеме 2,0-2,7 мл. Содержание белка в этих образцах составляло 0,336-0,683 мг/мл, гемагглютинирующая активность - 256000-512000 ГАЕ/мл. При иммунизации кроликов очищенными вируссодержащими суспензиями в дозе (по белку) 150 мкг/животное получили гипериммунные поликлональные сыворотки. Для дальнейшей работы сыворотки разводили в концентрации 1:10 и прогревали согласно стандартной процедуре при $56^{\circ} \mathrm{C}$ в течение 30 мин для инактивации термолабильных белков системы комплемента. Титры специфических антител полученных сывороток в РТГА с гомологичными штаммами составили 1:320 и 1:5120.

Иммунные кроличьи сыворотки, полученные к казахстанским штаммам вируса гриппа свиней, в титрах 1:160 подавляли гемагглютинирующую активность диагностикума (вирус гриппа А/H1N1). С гетерологичными вирусами A/H3N2 и типа В сыворотки не взаимодействовали.

1. Результаты перекрестной реакции торможения гемагглютинаци (РТГА) референсных штаммов вируса гриппа свиней $\mathrm{A}(\mathrm{H} 1 \mathrm{N1})$ и изолятов, выделенных в свиноводческих хозяйствах Северного Казахстана в 2018 году

\begin{tabular}{|c|c|c|c|c|c|c|}
\hline \multirow{2}{*}{ Изолят, штамм } & \multicolumn{6}{|c|}{ Антисыворотка к вирусам гриппа } \\
\hline & 1 & 2 & 3 & 4 & 5 & 6 \\
\hline А/свинья/Петропавловск/01/18 & 320 & 160 & 2560 & 1280 & 320 & 40 \\
\hline А/свинья/Петропавловск/02/18 & 160 & 320 & 2560 & 1280 & 160 & 40 \\
\hline А/свинья/Петропавловск/03/18 & 160 & 160 & 2560 & 1280 & 160 & 40 \\
\hline A/swine/USA/1976/31 & 80 & 160 & 1280 & 640 & 640 & 20 \\
\hline A/swine/Iowa/15/30 & 320 & 80 & 2560 & 640 & 640 & 40 \\
\hline A/California/04/09 pdm & 20 & 40 & 20 & 20 & 40 & 160 \\
\hline \multicolumn{7}{|c|}{$\begin{array}{l}\text { П р и м е ч а н и е. Представлены обратные значения титров антигемагглютининов. } 1 \text { - А/свинья/Петро- } \\
\text { павловск/01/18, } 2-\text { А/свинья/Петропавловск/02/18, } 3-\text { A/свинья/Петропавловск/03/18, } 4-\text { A/swi- } \\
\text { ne/USA/1976/31, } 5 \text { - A/swine/Iowa/15/30, } 6-\text { A/California/04/09 pdm. }\end{array}$} \\
\hline
\end{tabular}

Выделенные штаммы А/свинья/Петропавловск/01/18, А/свинья/Петропавловск/02/18 и А/свинья/Петропавловск/03/18 взаимодействовали с иммунными сыворотками к эталонным вирусам A/swine/USA/1976/31(H1N1) и A/swine/Iowa/15/30 (H1N1) в высоких титрах (табл. 1). С антисывороткой к дрейф-варианту A/California/04/09 (H1N1) pdm они реагировали в 
более низких титрах. По антигенной структуре гемагглютинина изучаемые штаммы существенно не различались между собой. Так, было выявлено антигенное родство вариантов вируса гриппа $\mathrm{A}(\mathrm{H} 1 \mathrm{~N} 1)$, выделенных от свиней, между собой и с референсными штаммами A/H1N1 (A/swine/USA/1976/31 и A/swine/Iowa/15/30), а также их отличие от штамма A/California/04/09 pdm.

Инфекционная активность выделенных штаммов вируса гриппа свиней на КЭ варьировала в пределах 6,5-7,9 lg ЭИД клеток MDCK - 3,5-4,3 lg ТЦД $50 / 0,2$ мл. По этому признаку они несколько уступали эталонным штаммам A/swine/Iowa/15/30 и A/swine/USA/1976/31 с показателями, составившими соответственно 8,7 и 8,0 lg ЭИД $50 / 0,2$ мл и 5,2 и 5,1 lg ТЦД $50 / 0,2$ мл (табл. 2). Штамм А/свинья/Петропавловск/01/18 по инфекционной активности оказался близок к эталонному штамму A/California/04/09 pdm.

По термочувствительности гемагглютинина тестируемые изоляты вируса гриппа свиней, аналогично референсным штаммам, были отнесены к термостабильным вариантам, поскольку сохраняли способность вызывать агглютинацию эритроцитов курицы в высоких титрах $\left(\log _{2}\right.$ от $6,3 \pm 0,6$

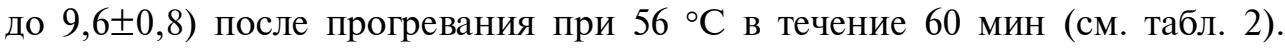
Установлено, что все изученные штаммы обладали хорошей адсорбирующей способностью по отношению к эритроцитам кур (90-100 \%); их элюция происходила в течение 30-60 мин инкубации при $37{ }^{\circ} \mathrm{C}$.

2. Основные биологические свойства изолятов вируса гриппа свиней $\mathrm{A} / \mathrm{H} 1 \mathrm{N1}$, выделенных в свиноводческих хозяйствах Северного Казахстана в 2018 году

\begin{tabular}{l|c|c|c|c|c|c}
\hline \multirow{2}{*}{ Изолят, штамм } & \multicolumn{3}{c|}{ ИА } & \multicolumn{2}{c|}{ ТГ Ад } & \multirow{2}{*}{ Эл } \\
\cline { 2 - 5 } & 1 & 2 & 3 & 4 & 90 \\
A/свинья/Петропавловск 01/18 & 6,5 & 3,5 & $9,7 \pm 0,2$ & $9,6 \pm 0,8$ & 1,0 \\
A/свинья/Петропавловск 02/18 & 7,8 & 4,3 & $9,6 \pm 0,4$ & $9,6 \pm 0,8$ & 100 & 1,0 \\
A/свинья/Петропавловск 03/18 & 7,9 & 4,3 & $9,7 \pm 0,6$ & $9,3 \pm 0,9$ & 100 & 0,5 \\
A/swine/Iowa/15/30 & 8,8 & 5,2 & $9,7 \pm 0,6$ & $6,3 \pm 0,6$ & 100 & 1,0 \\
A/swine/USA/1976/31 & 8,0 & 5,2 & $8,7 \pm 0,6$ & $6,6 \pm 0,6$ & 90 & 0,5 \\
A/California/04/09 pdm & 6,0 & 3,8 & $8,7 \pm 0,6$ & $6,6 \pm 0,6$ & 100 & 1,0 \\
\hline
\end{tabular}

П р и м е а н и е. ИА - инфекционная активность: 1 - для куриных эмбрионов, $\lg$ ЭИД $50 / 0,2$ мл, 2 для культуры клеток MDCK, lg ТЦД $50 / 0,2$ мл; ТГ - термостабильность гемагглютинина (GMT $\pm \mathrm{SD})$ : $3-$ исходный вирусный препарат, 4 - препарат после прогревания при $56^{\circ} \mathrm{C}$ в течение 60 мин; Ад - адсорбция на куриных эритроцитах, \%; Эл - время элюции с куриных эритроцитов при 37 $\mathrm{C}$, ч.

Выделенные штаммы вируса гриппа свиней, как и референсные варианты A/swine/Iowa/15/30 и A/swine/USA/1976/31, в высоких титрах активно агглютинировали все виды эритроцитов в эксперименте (табл. 3).

3. Гемагглютинирующая активность референсных штаммов вируса гриппа свиней $\mathrm{A}(\mathrm{H} 1 \mathrm{N1})$ и изолятов, выделенных в свиноводческих хозяйствах Северного Казахстана в 2018 году, по отношению к эритроцитам человека и различных животных $(\mathrm{GMT} \pm \mathrm{SD})$

\begin{tabular}{l|c|c|c|c|c}
\hline \multicolumn{1}{c|}{ Изолят, штамм } & Курица & $\begin{array}{l}\text { Морская } \\
\text { свинка }\end{array}$ & Баран & Лошадь & $\begin{array}{c}\text { Человек, группа } \\
\text { крови I(0) }\end{array}$ \\
\hline A/свинья/Петропавловск 01/18 & $9,5 \pm 0,4$ & $10,1 \pm 0,2$ & $10,0 \pm 0,0$ & $9,6 \pm 0,4$ & $10,4 \pm 0,2$ \\
A/свинья/Петропавловск 02/18 & $9,6 \pm 0,3$ & $10,5 \pm 0,4$ & $10,0 \pm 0,0$ & $9,7 \pm 0,2$ & $10,4 \pm 0,2$ \\
A/свинья/Петропавловск 03/18 & $9,5 \pm 0,4$ & $10,5 \pm 0,4$ & $10,0 \pm 0,0$ & $9,5 \pm 0,4$ & $10,3 \pm 0,0$ \\
A/swine/Iowa/15/30 & $9,7 \pm 0,6$ & $12,0 \pm 0,0$ & $9,5 \pm 1,4$ & $8,7 \pm 0,3$ & $9,6 \pm 1,5$ \\
A/swine/USA/1976/31 & $8,7 \pm 0,6$ & $11,0 \pm 0,0$ & $8,2 \pm 1,6$ & $9,7 \pm 0,4$ & $9,3 \pm 1,2$ \\
A/California/04/09 pdm & $8,7 \pm 0,6$ & $9,3 \pm 0,6$ & $6,6 \pm 0,6$ & $1,0 \pm 0,0$ & $8,0 \pm 0,0$
\end{tabular}

Пр и м е ч а н и е. Представлены среднегеометрические логарифмы (GMT) с основанием 2 для обратных титров гемагглютининов.

У всех тестируемых изолятов гемагглютинирующая активность не подавлялась неспецифическими нативными сыворотками взятых в эксперимент животных (табл. 4). Однако прогревание сывороток способствовало повышению их ингибирующей активности. Титры ингибиторов возрас- 
тали в сыворотках, прогретых 30 мин при температуре $62{ }^{\circ} \mathrm{C}$, и еще более - при кипячении в течение 10 мин при $100^{\circ} \mathrm{C}$.

4. Чувствительность изолятов вируса гриппа свиней A/H1N1, выделенных в свиноводческих хозяйствах Северного Казахстана в 2018 году, к неспецифическим ингибиторам сывороток крови различных животных

\begin{tabular}{|c|c|c|c|c|c|c|c|c|c|}
\hline \multirow{3}{*}{ Изолят, штамм } & \multicolumn{9}{|c|}{ Сыворотка крови } \\
\hline & \multicolumn{3}{|c|}{ морская свинка } & \multicolumn{3}{|c|}{ курица } & \multicolumn{3}{|c|}{ кролик } \\
\hline & 1 & 2 & 3 & 1 & 2 & 3 & 1 & 2 & 3 \\
\hline А/свинья/Петропавловск/01/18 & $<20$ & 20 & 160 & $<20$ & 40 & 80 & $<20$ & 20 & 20 \\
\hline А/свинья/Петропавловск/02/18 & $<20$ & 40 & 80 & $<20$ & 80 & 80 & $<20$ & 80 & 160 \\
\hline А/свинья/Петропавловск/03/18 & $<20$ & 40 & 80 & $<20$ & 160 & 160 & $<20$ & 80 & 160 \\
\hline $\mathrm{A} /$ swine/Iowa/15/30 & $<20$ & 40 & 80 & $<20$ & $<20$ & 40 & $<20$ & 80 & 160 \\
\hline A/swine/USA/1976/31 & $<20$ & 80 & 80 & $<20$ & $<20$ & 40 & $<20$ & 40 & 160 \\
\hline A/California/04/09 pdm & $<20$ & 40 & 80 & $<20$ & $<20$ & 40 & $<20$ & 80 & 80 \\
\hline
\end{tabular}

Пр и м е ч а н и е. 1 - нативные сыворотки, 2 - прогревание 30 мин при $62{ }^{\circ} \mathrm{C}, 3-$ кипячение 10 мин при $100{ }^{\circ} \mathrm{C}$. Представлены обратные величины титров неспецифических ингибиторов.

Предварительное изучение на КЭ не выявило эмбриотоксического действия взятых в эксперимент противовирусных препаратов во всех изученных дозах $(20,21)$.

Исследуемые изоляты вируса гриппа свиней A/H1N1, как и референсные штаммы, оказались чувствительными к тамифлю и ремантадину (табл. 5). Ингибирующая концентрация для них составила соответственно 5,6-6,6 и 3,7-12,7 мкг/мл. При этом изоляты, как и эталонные варианты, оказались резистентными к арбидолу и ингавирину, которые не ингибировали репродукцию вирусов даже в высокой концентрации (50 мкг/мл).

5. Чувствительность изолятов вируса гриппа свиней A/H1N1, выделенных в свиноводческих хозяйствах Северного Казахстана в 2018 году, к противовирусным препаратам $(\mathrm{GMT} \pm \mathrm{SD})$

\begin{tabular}{l|c|c|c|c}
\hline \multirow{2}{*}{ Изолят, штамм } & \multicolumn{4}{c}{ Ингибирующая концентрация, мкг/мл } \\
\cline { 2 - 5 } & тамифлю & ремантадин & арбидол & ингавирин \\
\hline A/свинья/Петропавловск/01/18 & $6,6 \pm 0,1$ & $6,9 \pm 0,0$ & Не ингибирует & Не ингибирует \\
A/свинья/Петропавловск/02/18 & $5,6 \pm 2,0$ & $12,7 \pm 0,1$ & Не ингибирует & Не ингибирует \\
A/свинья/Петропавловск/03/18 & $5,7 \pm 1,7$ & $3,7 \pm 0,2$ & Не ингибирует & Не ингибирует \\
A/swine/Iowa/15/30 & $6,5 \pm 0,1$ & $6,7 \pm 0,2$ & Не ингибирует & Не ингибирует \\
A/swine/USA/1976/31 & $6,6 \pm 0,6$ & $7,0 \pm 0,1$ & Не ингибирует & Не ингибирует \\
A/Сalifornia/04/09 pdm & $3,5 \pm 0,0$ & Не ингибирует & Не ингибирует Не ингибирует \\
П р и м е ч а н и е. Указана концентрация препарата, вызывающая снижение репродукции вируса в кури- \\
ных эмбрионах в 2 раза.
\end{tabular}

Суммируя полученные данные, отметим, что сравнение биологических свойств вирусов гриппа свиней, изолированных на территории Республики Казахстана в 2018 году, и штаммов, выделенных в 2010-2016 годах $(9,22)$, показало, что по основным биологическим свойствам они представляют собой в основном однородную группу. Изоляты проявляли незначительную антигенную гетерогенность, что свидетельствуют о продолжительной циркуляции антигенно однородных штаммов вирусов гриппа среди свиней, и большее сходство эталонными вариантами вируса гриппа свиней (A/swine/USA/1976/31 и A/swine/Iowa/15/30), чем с циркулирующими в популяции людей после 2009 года штаммами вируса гриппа A/H1N1, родственными A/California/04/09 pdm. Восприимчивость к вирусам гриппа А птиц и человека, выявляемая у свиней, позволяет считать их промежуточным хозяином, в организме которого происходит реассортация между генами вирусов гриппа различного происхождения. Этот процесс может приводить к возникновению новых антигенных вариантов вируса гриппа с эпидемическим потенциалом (23). Степень патогенности и эпидемической активности неодинакова для различных вариантов вируса 
гриппа и зависит как от молекулярно-биологических свойств штаммов, так и от особенностей их экологии. При сравнении штаммов вируса гриппа в перекрестной РТГА определяется характер их серологических отношений, которые могут отражать небольшие антигенные различия по гемагглютинину между сходными штаммами и/или указывать на различия между группами штаммов $(24,25)$.

Таким образом, штаммы вируса гриппа свиней, выделенные из проб, собранных от животных в Северном Казахстане в 2018 году, по антигенной формуле были сходны между собой и со штаммами, циркулировавшими ранее в популяции свиней на территории Республики Казахстан, а также с классическими эталонами вируса гриппа свиней, но отличались от штаммов, циркулирующих в человеческой популяции. Изоляты, выделенные в 2018 году, были сходны друг с другом и с референсными штаммами по термостабильности гемагглютинина и скорости адсорбции на куриных эритроцитах, но различались по скорости элюции с эритроцитов, чувствительности к противовирусным препаратам, а также по инфекционной активности. Два штамма вируса гриппа свиней - А/свинья Петропавловск/02/18 и А/свинья Петропавловск/03/18 по инфекционности были близки к эталонным штаммам A/swine/Iowa/15/30 и A/swine/USA/1976/31, тогда как штамм А/свинья/Петропавловск/01/18 по этому признаку проявил сходство с эталонным вариантом A/California/04/09 pdm. Выявлена чувствительность изолятов к противовирусным препаратам тамифлю и ремантадину и резистентность к арбидолу и ингавирину. Изучение антигенных и биологических свойств вирусов гриппа животных позволяют установить закономерности циркуляции патогена и развития инфекционного процесса, составить прогноз эпидемической ситуации и выбрать адекватную стратегию и тактику проведения профилактических и противоэпидемических мероприятий. При этом крайне актуально выявление вновь возникающих вариантов вируса в популяциях восприимчивых к гриппу видов животных, в особенности свиней, в связи с чем мы планируем продолжить мониторинговые исследования.

\section{ЛИТЕРАТУРА}

1. Lvov D.K. Influenza A viruses - a sum of populations with a common protected gene pool. In: Soviet medical reviews. Section E. Virology reviews /V.M. Zhdanov (ed.). Bell and Bain Ltd., Glasgow, 1987, V. 2: 15-37.

2. Webster R.G., Bean W.J., Gorman O.T., Chambers T.M., Kawaoka Y.C. Evolution and ecology of influenza A viruses. Microbiological Reviews, 1992, 56(1): 152-179 (doi: 10.1128/MMBR.56.1.152179.1992).

3. Hinshaw V.S., Webster R.G., Bean W.J., Downie J., Senne D.A. Swine influenza-like viruses in turkeys: potentional source of virus for humans? Science, 1983, 220(4593): 206-208 (doi: 10.1126/science.6298942).

4. Swine Influenza (Influenza in Swine). Режим доступа: https://www.cdc.gov/flu/swineflu/influenzain-swine.htm. Дата обращения: 20.08.2019.

5. ВОЗ. Вспышка гриппа среди людей, вызванная гриппом A/H1N1, - соображения по поводу перехода вируса от животного $\kappa$ человеку. 30 апреля 2009 года. Режим доступа: https://www.google.ru/url?sa $=t \& r c t=j \& q=\& e s r c=s \&$ source $=$ web\&cd $=1 \& \mathrm{cad}=$ rja\&uact $=8 \& v e d=$ 2ahUKEwi6sdz9s6niAhUNuIsKHep6AngQFjAAegQIARAC\&url=http\%3A\%2F\%2Forigin.who.i nt\%2Fentity\%2Ffoodsafety\%2Ffs_management\%2FNo_02_influenza_Apr09_ru_rev1.pdf\&usg= AOvVaw1143P4XoJ-JgAeEUsOOJDI. Дата обращения: 20.05.2019.

6. Simon G., Larsen L.E., Dürrwald R., Foni E., Harder T., Van Reeth K., Markowska-Daniel I., Reid S.M., Dan A., Maldonado J., Huovilainen A., Billinis C., Davidson I., Agbero M., Vila T., Hervé S., Breum S.Ø., Chiapponi C., Urbaniak K., Kyriakis C.S., ESNIP3 consortium, Brown I.H., Loeffen W. European surveillance network for influenza in pigs: surveillance programs, diagnostic tools and Swine influenza virus subtypes identified in 14 European countries from 2010 to 2013. PloS ONE, 2014, 9(12): e115815 (doi: 10.1371/journal.pone.0115815).

7. Лукманова Г.В., Кливлеева Н.Г., Шаменова М.Г., Сактаганов Н.Т., Глебова Т.И., Му- 
стафин М.К., Баисеев Г.А., Мустафин Б.М. Серологический анализ циркуляции вирусов гриппа А среди свиней в Казахстане в 2013-2014 гг. Ветеринария, 2016, 1(45): 61-63.

8. Klivleyeva N.G., Saktaganov N.T., Glebova T.I., Lukmanova M.G., Shamenova M.G., Sayatov M.H. Detection of influenza A(H1N1) viruses in humans and pigs in the Northern Kazakhstan during 2014-2016. Int. Conf. Symp. «Influenza 2018: Centenary of the 1918 Pandemic». London, 2018: 38.

9. Сактаганов Н.Т., Кливлеева Н.Г., Глебова Т.И., Калкожаева М.К., Лукманова Г.В., Онгарбаева Н.С., Байсейит С.Б., Баймухаметова А.М., Шаменова М.Г. Характеристика биологических свойств изолятов вируса гриппа свиней А/H1N1, выделенных в Актюбинской области в 2014 году. Ветеринария, 2019, 2: 21-25 (doi: 10.30896/0042-4846.2019.22.2.21-25).

10. Brown I.H., Done S.H., Spencer Y.I., Cooley W.A., Harris P.A., Alexander D.J. Pathogenicity of a swine influenza H1N1 virus antigenically distinguishable from classical and European strains. Veterinary Record, 1993, 132(24): 598-602 (doi: 10.1136/vr.132.24.598).

11. Factsheet on swine influenza in pigs. Режим доступа: https://www.ecdc.europa.eu/en/swineinfluenza/facts/swine-influenza-pigs. Дата обращения: 20.05.2019.

12. Ma J., Shen H., McDowell C., Liu Q., Duff M., Lee J., Lang Y., Hesse D., Richt J.A., Ma W. Virus survival and fitness when multiple genotypes and subtypes of influenza A viruses exist and circulate in swine. Virology, 2019, 532: 30-38 (doi: 10.1016/j.virol.2019.03.016).

13. Соминина А.А., Бурцева Е.И., Лобова Т.Г., Коновалова Н.И., Гудкова Т.М., Литвинова О.М., Слепушкин А.Н., Иванова В.Т. Выделение вирусов гриппа в клеточных культурах и куриных эмбрионах и их идентификации. Методические рекомендации (утверждены ФС по надзору в сфере защиты прав потребителей и благополучия человека). 18 апреля 2006 г. № 0100/4430-06-34. Режим доступа: http://docs.cntd.ru/document/420214503. Дата обращения: 20.05.2019.

14. WHO Global Influenza Surveillance Network. Manual for the laboratory diagnosis and virological surveillance of influenza. WHO Press, Geneva, 2011. Режим доступа: http://apps.who.int/bookorders/MDIbookPDF/Book/11500806.pdf?ua=1. Дата обращения: 28.04.2018.

15. Archetti I., Horsfall F.L. Jr. Persistent antigenic variation of influenza a viruses after incomplete neutralization in ovo with heterologous immune serum. Journal of Experimental Medicine, 1950, 92(5): 441-462 (doi: 10.1084/jem.92.5.441).

16. Reed L., Muench H. A simple method of estimation fifty percent and pints. American Journal of Tropical Medicine and Hygiene, 1938, 27(20): 493-497.

17. Cloud S.S., Rosenberger J.K. Characterization of nine avian paramyxoviruses. Avian Diseases, 1986, 24(1): 139-152 (doi: 10.2307/1589773).

18. Ito T., Suzuki Y., Mitnaul L., Vines A., Kida H., Kawaoka Y. Receptor specificity of influenza A viruses correlates with the agglutination of erythrocytes from different animal species. Virology, 1997, 227(2): 493-499 (doi: 10.1006/viro.1996.8323).

19. Руководство по экспериментальному (доклиническому) изучению новых фармакологических веществ /Под ред. Р.У. Хабриева. М., 2005.

20. Tare D.S., Pawar S.D. Use of embryonated chicken egg as a model to study the susceptibility of avian influenza H9N2 viruses to oseltamivir carboxylate. Journal of Virological Methods, 2015, 224: 67-72 (doi: 10.1016/j.jviromet.2015.08.009).

21. Логинова С.Я., Борисевич С.В., Максимов В.А., Бондарев В.П. Оценка токсичности неспецифических медицинских противовирусных средств, предназначенных для профилактики и лечения опасных и особо опасных вирусных инфекций. Антибиотики $u x u$ миотерапия, 2009, 54(3-4): 11-14.

22. Онгарбаева Н.С., Сактаганов Н.Т., Калкожаева М.К., Лукманова Г.В., Баймухаметова А.М., Глебова Т.И., Кливлеева Н.Г. Антигенные взаимосвязи и биологические свойства штаммов вируса гриппа свиней А/H1N1, выделенных в 2013-2014 гг. на территории республики Казахстан. Мат. IV Межд. науч. конф. «Достижения молодых ученых в ветеринарную практику», посвященной 55-летию аспирантуры ФГБУ ВНИИЗЖ. Владимир, 2016: 99-103.

23. Киселев О.И. Геном пандемического вируса грипnа A/H1N1v-2009. СПб-М., 2011.

24. Табынов К.К., Мамадалиев С.М., Азанбекова М.А., Мамбеталиев М. Антигенные взаимосвязи высокопатогенных штаммов вируса гриппа птиц А/H5N1, выделенных на территории Республики Казахстан в 2005-2006 годы. Актуальные вопросы ветеринарной биологии, 2009, 4(4): 8-11.

25. Cai M., Huang J., Bu D., Yu Z., Fu X., Ji C., Zhou P., Zhang G. Molecular evolution of H1N1 swine influenza in Guangdong, China, 2016-2017. Infection, Genetics and Evolution, 2018, 60: 103-108 (doi: 10.1016/j.meegid.2018.02.029).

\section{ТОО Научно-производственный иентр}

\section{«Микробиологии и вирусологии»,}

А26Т6С0 Республика Казахстан, г. Алматы, ул. Богенбай батыра, 105, e-mail: biochem_vir@mail.ru, nsaktaganov1984@mail.ru $₫$, i_nailya@list.ru, nuray.syrlybay@gmail.com, taty1962@mail.ru,gal_1@bk.ru,

a_baimukhametova@mail.ru
Поступила в редакиию 21 октября 2019 года 


\title{
STUDY ON ANTIGENIC RELATIONSHIPS AND BIOLOGICAL PROP- ERTIES OF SWINE INFLUENZA A/H1N1 VIRUS STRAINS ISOLATED IN NORTHERN KAZAKHSTAN IN 2018
}

\author{
N.T. Saktaganov, N.G. Klivleyeva, N.S. Ongarbayeva, T.I. Glebova, \\ G.V. Lukmanova, A.M. Baimukhametova
}

Research and Production Center for Microbiology and Virology, A26T6C0 Republic of Kazakhstan, Almaty, st. Bogenbai Batyr, 105, e-mail biochem_vir@mail.ru, nsaktaganov1984@mail.ru (凹 corresponding author), i_nailya@list.ru,nuray.syrlybay@gmail.com, taty1962@mail.ru,gal_1@bk.ru,a_baimukhametova@mail.ru

ORCID:

Saktaganov N.T. orcid.org/0000-0001-6526-956X

Klivleyeva N.G. orcid.org/0000-0002-4094-137X

Ongarbayeva N.S. orcid.org/0000-0001-9022-331X

The authors declare no conflict of interests

Received October 21, 2019

Glebova T.I. orcid.org/0000-0002-1139-9868

Lukmanova G.V. orcid.org/0000-0002-9809-6674

Baimukhametova A.M. orcid.org/0000-0002-8959-126X

doi: 10.15389/agrobiology.2020.2.355eng

\section{Abstract}

Swine influenza is a highly contagious acute disease characterized by pronounced fever, general weakness, and disorders of the respiratory system. Swine influenza virus can cause disease in humans and, on the contrary, swine may be infected by human influenza virus. In the pig's organism, simultaneously infected with viruses of different origin, genetic reassortment takes place with the risk of occurrence of new dangerous highly pathogenic strains. The study of influenza viruses circulating in the pig population therefore plays an important role in preventing the development of dangerous outbreaks of the disease and planning preventive measures. In this work we studied the characteristics of the newly isolated strains of swine influenza virus which are epizootically relevant in the specified region at the present time. Our purpose was to identify the biological and antigenic characteristics of strains of swine influenza A/H1 N1virus, circulating in the North Kazakhstan oblast of the Republic of Kazakhstan in 2018. Influenza A/H1 N1 virus strains were studied including those isolated from pigs in pig farms of the North Kazakhstan oblast, the A/swine/Petropavlovsk/01/18, $\mathrm{A} /$ swine/Petropavlovsk/02/18, and $\mathrm{A} /$ swine/Petropavlovsk/03/18, and also the reference strains A/swine/Iowa/15/30, A/swine/USA/1976/31, and A/California/04/09 pdm. The strains were cloned in 10-day-old developing chicken embryo systems. The antigenic properties of surface glycoproteins of the strains were examined by cross-reactivity hemagglutination inhibition assay with rabbit immune sera. Infectivity was determined in chicken embryos (CE) and MDCK cell culture. The adsorption properties were studied on formalinized chicken red blood cells under constant stirring at $4{ }^{\circ} \mathrm{C}$ for 18 hours. Elution from red blood cells was determined after 30, 60, 120, 180, and $240 \mathrm{~min}$ in buffered saline at $37{ }^{\circ} \mathrm{C}$. The heat sensitivity of hemagglutinin was assessed by the ability to agglutinate red blood cells after heating at $56^{\circ} \mathrm{C}$ for $5,10,15,30$, and 60 minutes. The hemagglutinating activity of strains was assayed using $0.75 \%$ suspensions of chicken, guinea pig, ram, horse, and blood group I(0) individual erythrocytes. The susceptibility of isolates to nonspecific inhibitors was determined in the hemagglutination inhibition assay with native and heated $\left(30 \mathrm{~min}\right.$ at $62{ }^{\circ} \mathrm{C}$ and 10 min at $100{ }^{\circ} \mathrm{C}$ ) blood sera of guinea pig, chicken, and rabbit. The susceptibility of virus strains to different concentrations of antiviral drugs was evaluated by the level of reproductive suppression of lg $100 \mathrm{EID}_{50} / 0.2 \mathrm{ml}$ of virus in CE. The antigenic relationship of the examined variants of influenza A/H1N1 virus between each other and with the reference strains A/swine/USA/1976/31 and $\mathrm{A} / \mathrm{swine} / \mathrm{Iowa} / 15 / 30$ was revealed as well as their difference from the strain A/California/04/09 pdm. The studied strains in high titers agglutinated all types of red blood cells taken in the experiment. The infectious activity of swine influenza virus strains ranged within 6.5-7.9 $\mathrm{lg} \mathrm{EID}_{50} / 0.2 \mathrm{ml}$ in chicken embryos, and 3.5-4.3 $\mathrm{lg} \mathrm{TCD}_{50} / 0.2 \mathrm{ml}$ in MDCK cell culture. After heating at $56{ }^{\circ} \mathrm{C}$, all strains agglutinated chicken erythrocytes in high titers $\left(\log _{2}=6.3 \pm 0.6-9.6 \pm 0.8\right)$ and were characterized as thermostable. The isolated strains possessed good adsorption ability against chicken erythrocytes (90-100\%) and eluted from them after 30-60 min incubation at $37{ }^{\circ} \mathrm{C}$. The strains revealed inhibitory resistance with native nonspecific sera and were suppressed by inhibitors of the heated sers only. The studied strains proved to be susceptible to Tamiflu and Remantadine (the inhibitory concentrations were 5.6-6.6 and 3.7-12.7 $\mu \mathrm{g} / \mathrm{ml}$, respectively). Viruses exhibited resistance to the drugs Arbidol and Ingavirin. Thus, the study revealed similarity of isolated and reference A/H1N1 strains in thermostability of the hemagglutinin, adsorption rate and susceptibility to antiviral drugs, as well as differences in infectious activity and the rate of elution from chicken red blood cells.

Keywords: swine influenza virus, A/H1N1, strain, isolate, antigen, hemagglutinin, infectivity, thermostability, resistance, drug susceptibility. 